\title{
Dental and Oral Health Education for Elderly Age Group: Full and Partial Edentulous Teeth Brushing Method by Titiek Berniyanti
}

Submission date: 27 -Jun-2019 10:49AM (UTC+0800)

Submission ID: 1147363783

File name: JlntOralHealth112104-7552409_205844.pdf (353.17K)

Word count: 2241

Character count: 11734 


\title{
Dental and Oral Health Education for Elderly Age Group: Full and Partial Edentulous Teeth Brushing Method
}

\author{
Titiek Berniyanti, Aryo Dwipo Kusumo, Taufan Bramantoro, Gilang Rasuna Sabdho Wening, Retno Palupi \\ Department of Dental Public Health, Faculty of Dental Medicine, Universitas Airlangga, Surabaya, Indonesia
}

\section{Abstract}

\begin{abstract}
Aims: The objective of this research is to form independent cadres and could provide counseling and training on how to brush full/partial edentulous teeth the right way to the elderly in nursing home. Materials and Methods: This descriptive study was conducted with 12 participants with posttest only group design. Participants are given the theory of toothbrushing method of edentulous teeth, practical demonstration, and evaluation. To measure the knowledge level, there is a posttest and socialization ability test for respondents. Results: The average achievement percentage of respondents about knowledge and application of the elderly toothbrushing method was $96.67 \%$, and the achievement percentage of respondent's success about the socialization ability was $87.66 \%$. Conclusions: Based on empowerment results, most cadres understood about how to brush elderly teeth properly and socialize it to their elderly friends about how to brush their teeth properly.
\end{abstract}

Keywords: Cadres, empowerment, toothbrushing habits

\section{INTRODUCTION}

Dental and oral disease is a disease that affects all age groups, from children to adults, and there is no exception in the elderly group. ${ }^{[1]}$ One of the health problems in the elderly is dental caries. ${ }^{[2]}$ Teeth have functions for mastication, speech, and esthetics. Teeth of the elderly may have been damaged and even dislodged, giving difficulties when chewing food. Tooth loss is the most common cause of mastication malfunction. Tooth loss can also affect the oral cavity and general health. Thus, it affects the quality of life as a whole. Tooth loss can be caused by various factors. ${ }^{[3]}$ The most common cause of tooth loss is the adverse health status of the oral cavity, especially caries and periodontal disease ${ }^{[4]}$ Based on the results of the assessment of problems obtained from the previous epidemiological research reports, $47.25 \%$ of 91 respondents have poor mastication function. Cross tabulation of decayed, missing, and filled (DMF) index with mastication function stated that elderly population with DMF index $>13$ is 1.49 times higher to have poor mastication function.

The Public Health Centre has tried to tackle dental health problems in the elderly by conducting some health promotion program. One of them is counseling and providing knowledge

\begin{tabular}{|l|l|}
\hline \multicolumn{2}{|c|}{ Access this article online } \\
\hline Quick Response Code: & $\begin{array}{l}\text { Website: } \\
\text { www.jioh.org }\end{array}$ \\
& \\
& DOI: \\
\hline
\end{tabular}

on dental and oral health for elderly. This can also be done with the formation of dental and oral health cadres who play a role in monitoring elderly dental hygiene in the elderly nursing home activities. ${ }^{[5]}$ Community empowerment method with cadre formation has been applied in Jagir Health Center, Surabaya, East Java. However, based on discussions with the health center staffs, the cadre program has not run optimally. In order to help overcome the high rates of DMF in the elderly, cadres were tasked with learning how to brush the edentulous ridge properly and correctly, to then teach it to peers.

The target of this program is the cadres from nursing house The aims of this program are that cadres are able to understand how to clean dentures correctly, cadres are able to convey information about how to clean dentures correctly, cadres are able to demonstrate to fellow elderly friends on how to properly clean dentures, and elderly people are able to demonstrate and apply methods clean denture correctly.

Address for correspondence: Dr. Titiek Berniyanti, Jl. Prof Dr. Moestopo, No. 47, Surabaya, Indonesia. E-mail: berniyanti@gmail.com

This is an open access journal, and articles are distributed under the terms of the Creative Commons Attribution-NonCommercial-ShareAlike 4.0 License, which allows others to remix, tweak, and build upon the work non-commercially, as long as appropriate credit is given and the new creations are licensed under the identical terms.

For reprints contact: reprints@medknow.com

How to cite this article: Berniyanti T, Kusumo AD, Bramantoro T, Wening GR, Palupi R. Dental and oral health education for elderly age group: Full and partial edentulous teeth brushing method. J Int Oral Health 2019;11:104-6. 


\section{Materials and Methods}

The sampling used the simple random sampling which was conducted on 12 persons from 8 nursing home for the elderly. All the procedures done in this empowerment were approved by the Health Research Ethical Committee of Airlangga University Dentistry Faculty with letter number 59/KKEPK. FKG/VI/2015. Respondents filled the informed consent before starting the research. Researchers were explaining about objective, procedure, benefit, and confidentiality of research to the respondents before they sign the informed consent.

The empowerment research was carried out in several stages: giving material, evaluating cadres, and counseling by cadres. Respondents were the elderly who were obtained from nursing homes. Initially, a pretest was conducted to measure the level of knowledge of nursing home cadres. Respondents were given counseling about dental and oral health materials, as well as ways to brush their teeth on their jaws which had no teeth. After that, a posttest was carried out to find out how much cadre knowledge increased. If the posttest results reach a predetermined target, the cadres can teach them to other elderly people.

Dental health education method used was a demonstration in front of the cadres. This program was done by individual approach. The demonstration was to demonstrate directly about the correct full/partial edentulous brushing method with a dental phantom that was formed in such a technique as to resemble the anatomical form of the oral cavity of the elderly to make the material more easily to be understood. Furthermore, cadres who are considered to have fulfilled the requirements for counseling were asked to teach other elderly about the material with the same health education media. Other elderly who were taught were reevaluated.

\section{REsULTS}

The oral and dental health education program on how to properly brush the edentulous teeth was carried out on 12 cadres from 8 Posyandu for the elderly. The achievement of success obtained from observations on elderly cadres about the knowledge and application of the correct method of brushing teeth for the elderly is as follows [Table 1].

Nine out of a total of 12 cadres received a $100 \%$ percentage score for demonstrating the right way to brushing teeth in edentulous ridge. 2 cadres got $90 \%$ score and 1 cadre got $80 \%$ as the lowest score. Moreover, the average percentage of achievement of the success of elderly cadres about knowledge and the application of the elderly version of brushing is $96.67 \%$.

The achievement of success obtained from observations on elderly cadres about the ability to socialize the correct way of brushing teeth the elderly version is as follows [Table 2].

In the Sari Asih Posyandu, the achievements obtained by cadres about the ability to socialize the correct way of brushing teeth in the elderly is $80 \%$, whereas the attainment of cadres of the Loka

\begin{tabular}{|c|c|c|c|c|}
\hline No. & $\begin{array}{l}\text { Cadre } \\
\text { name }\end{array}$ & $\begin{array}{l}\text { Elderly nursing } \\
\text { home origin }\end{array}$ & $\begin{array}{c}\text { Achievement* } \\
(\%)\end{array}$ & $\begin{array}{c}\text { Target } \\
(\%)\end{array}$ \\
\hline 1 & Wahyudi & $\begin{array}{l}\text { Pelangi } \\
\text { Nusantara }\end{array}$ & 100 & 100 \\
\hline 2 & Yanti & Sawunggaling & 100 & 100 \\
\hline 3 & $\begin{array}{l}\text { Surya } \\
\text { Wijaya }\end{array}$ & Sari Asih & 100 & 100 \\
\hline 4 & Mulyani & Pramoda Loka & 100 & 100 \\
\hline 5 & Soehartati & Pramoda Loka & 90 & 100 \\
\hline 6 & Sumariyati & Kartika & 100 & 100 \\
\hline 7 & Siti Rahaju & Kartika & 100 & 100 \\
\hline 8 & Sulis A. & Mentari & 100 & 100 \\
\hline 9 & Soetjipto & Mentari & 90 & 100 \\
\hline 10 & Herryanto & Pertiwi & 100 & 100 \\
\hline 11 & Sudarwati & Adi Darma & 100 & 100 \\
\hline 12 & Mita & Adi Darma & 80 & 100 \\
\hline
\end{tabular}

Table 2: Percentage of achievement about socialization ability of elderly toothbrushing technique

\begin{tabular}{lllcc}
\hline No. & $\begin{array}{l}\text { Cadre } \\
\text { name }\end{array}$ & $\begin{array}{l}\text { Elderly nursing } \\
\text { home origin }\end{array}$ & $\begin{array}{c}\text { Achievement* } \\
\mathbf{( \% )}\end{array}$ & $\begin{array}{c}\text { Target } \\
(\mathbf{\%})\end{array}$ \\
\hline 1 & Surya & Sari Asih & 80 & 100 \\
& Wijaya & Pramoda Loka & 90 & 100 \\
2 & Mulyani & Pramoda Loka & 90 & 100 \\
3 & Soehartati & Mentari & 87.14 & 100 \\
4 & Sulis A & Mentari & 87.14 & 100 \\
5 & Soetjipto & Pertiwi & 91.67 & 100 \\
6 & Herryanto & Sawunggaling & 80 & 100 \\
7 & Yanti & Adi Darma & 80 & 100 \\
8 & Sudarwati & Adi Darma & 91.67 & 100 \\
9 & Mita & Kartika & 80 & 100 \\
10 & Sumariyati & Kartika & 90 & 100 \\
11 & Siti Rahaju & Pelangi & & 100 \\
12 & Wahyudi & Nusantara & & \\
\hline
\end{tabular}

Mean: $86.23 \%$, ${ }^{*}$ Posttest score

Pramoda is $90 \%$. In the Posyandu Mentari, the achievement obtained by the cadres on the ability to socialize the correct way of brushing teeth is the elderly, which is equal to $87.14 \%$, whereas the achievement of Posyandu Pertiwi cadres is $91.67 \%$. Moreover, the percentage of achievement of the success of elderly cadres about the ability in the socialization of the elderly version of brushing is $86.23 \%$.

\section{Discussion}

Dental and oral health education program on how to brush the edentulous teeth was conducted on 12 cadres from 8 nursing home for the elderly. The indicator of the success of this program is the increasing knowledge of cadres and cadres can teach how to brush edentulous teeth properly 
and correctly in other elderly. This can be seen in the results of observations on the cadres of the elderly about the knowledge and understanding of how to brush the correct version of the elderly. During the implementation of the empowerment program, the demonstration method was used with phantom media, toothbrushes, and posters so that speakers and cadres of the elderly could more easily understand the material. ${ }^{[6,7]}$ At the time of giving the materials, the voice of the speaker could be heard well by the cadres of the elderly. Many elderly people are active in giving questions spontaneously on the sidelines of the material given so that the atmosphere of empowerment lasts life. After the material has been given, the elderly cadres are tested using indicators of success that have been prepared to ensure that the cadre is ready to go into the community to do counseling.

The results of observations on elderly cadres about the ability to socialize the correct way of brushing teeth are also high. This is known from the results of observations on the elderly at who were given counseling by the cadres on how to brush edentulous teeth in correct way. The way to deliver material from cadres to the elderly was considered quite interesting with the help of phantom (Dental Study Model) and toothbrushes given. ${ }^{[8.9]}$ There is also an $\mathrm{A} 3$ poster-containing material on how to brush the edentulous teeth in correct way which is useful for facilitating the elderly to understand the material provided and to recall it because the poster was given ${ }^{[10]}$ and left at the Public Health Center.

The limitation of this study is we only conducted pretest and posttest, while the aim of this study is to maintain the habit of brushing denture. For further research, the researcher can conduct comparison between denture cleanser compositions and the effect on using it.

Overall, the elderly can demonstrate how to brush their teeth properly and correctly for the edentulous ridges, and teach the technique to their peers. Furthermore, the elderly at the Posyandu demonstrate and apply how to brush their teeth properly.

\section{Conclusions}

This program is effective to increase elderly knowledge about edentulous ridge toothbrushing method. The cadres managed to convey the material given.

\section{Acknowledgment}

The authors would like to thank the Department of Dental Public Health, Faculty of Dental Medicine, Universitas Airlangga.

\section{Financial support and sponsorship}

Nil.

\section{Conflicts of interest}

There are no conflicts of interest.

\section{REFERENCES}

1. John JR, Daniel B, Paneerselvam D, Rajendran G. Prevalence of dental caries, oral hygiene knowledge, status, and practices among visually impaired individuals in Chennai, Tamil Nadu. Int J Dent 2017;2017:9419648.

2. Alhamda S. Oral hygiene and dental caries status (study on 12-year-old group students at Bukit Tinggi state elementary school). Pub Med News 2011:27:108-15.

3. Khanna SS, Dhaimade PA, Malhotra S. Oral health status and fertility treatment including IVF. J Obstet Gynaecol India 2017:67:400-4.

4. Alanazi KJ, Subhan SA, Alshehri HM, Aljaload MM, Aljafary MH, Alazmi MM, et al. Influence of tooth brush grips and brushing techniques (8) plaque removal efficacy. J Dent Oral Health 2017;4:1-6.

5. Newman M, Takei H, Klokkevold P, Carranza F. Carranza's Clinical Periodontology. $13^{\text {th }}$ ed. Philadephia: Saunders-Elsevier; 2018. p. 237.

6. Sumawinata N. Restorative Conservation Manual According to Pickard 6. ed. Jakarta: Widya Medika; 2004. p. 6-8.

7. Laverack G. Health Promotion Practice: Power and Empowerment. London: Sage Publication; 2004. p. 19-24.

8. Tkatch R, Musich S, MacLeod S, Alsgaard K, Hawkins K, Yeh CS Population health management for older adults: Review of interventions for promoting successful aging across health continumm. J Geriatr Med Gerontol 2016;2:1-13.

9. Labonte R, Laverack G. Health Promotion in Action. England: Palgrave Macmillan; 2008. p. 25-38.

10. Golinowska S, Groot W, Baji P, Pavlova M. Health promotion targeting older people. BMC Health Serv Res 2016;16 Suppl 5:345. 
Dental and Oral Health Education for Elderly Age Group: Full and Partial Edentulous Teeth Brushing Method

ORIGINALITY REPORT

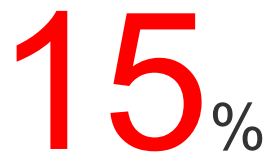

SIMILARITY INDEX
$13 \%$

INTERNET SOURCES
$5 \%$

PUBLICATIONS
$11 \%$

STUDENT PAPERS

\section{PRIMARY SOURCES}

1 www.shroffeyecentre.com

Internet Source

2 Submitted to Queen Mary and Westfield College

Student Paper

3 link.springer.com

Internet Source

4 repository.unair.ac.id Internet Source

Mohammad Ali Leghari, Syed Inayat Ali, Faisal Rehan, Humera Ali, Usman Shoukat Ali Arain.

"Prevalence of oral hygiene aids and bleeding

gums among the people visiting Private Dental

Hospital in Gadap town, Karachi", International

Dental \& Medical Journal of Advanced

Research - VOLUME 2015, 2017

Publication 
7 surgicalneurologyint.com

8 journals.plos.org

Internet Source

9 Pramono, C.. "Surgical Technique for Achieving Implant Parallelism and Measurement of the Discrepancy in Panoramic Radiograph", Journal of Oral and Maxillofacial Surgery, 200605

Publication

10 Submitted to Western Governors University Student Paper

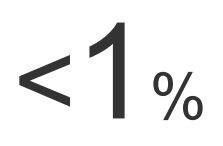

11 Submitted to University of Melbourne Student Paper 


\section{Dental and Oral Health Education for Elderly Age Group: Full and Partial Edentulous Teeth Brushing Method}

FINAL GRADE

$/ 100$
GENERAL COMMENTS

Instructor

\section{PAGE 1}

\section{PAGE 2}

